\title{
NATURAL DISASTERS AND THEIR IMPACT: A METHODOLOGICAL REVIEW
}

\author{
Fernando Antonio Ignacio González \\ Institute of Economic and Social \\ Research of the South \\ Bahía Blanca, Buenos Aires, Argentina \\ faigonzalez@iiess-conicet.gob.ar
}

\author{
Silvia London \\ Institute of Economic and Social \\ Research of the South \\ Bahía Blanca, Buenos Aires, Argentina \\ slondon@uns.edu.ar
}

Reception date: 03/31/2020 - Revision date: 07/10/2020 - Approval date: 08/06/2020

DOI: https://doi.org/10.36995/j.visiondefuturo.2021.25.01.002.en

\begin{abstract}
Natural disasters generate profound socio-economic changes in the affected communities. A consistent methodology that allows quantifying its impacts is essential for the implementation of adaptation and mitigation policies. The objective of this work is to provide a systematic review of existing methodologies to quantify the economic impact derived from the occurrence of natural disasters. To do this, a keyword search is conducted in two search engines (Scopus and Science Direct).

The results suggest the existence of wide differences between methodological proposals. Consideration of physical damage (direct effect) is more frequent than the impact on productive flows (indirect effect). The destruction of the natural environment (loss of ecosystem services) is not usually included. In the context of global climate change, these findings highlight the importance of having a consistent methodology.
\end{abstract}

KEY WORDS: Natural disasters; Economic impact.

\section{INTRODUCTION}

Natural disasters constitute a serious threat at the global level. Every year an increasing number of natural disasters take place (Center for Research on the Epidemiology of Disasters [CRED], 2020) and this is expected to deepen in the future as a consequence of climate change (Intergovernmental Panel on Climate Change [IPCC], 2018). During 2018 alone, natural disasters affected 68.5 million people worldwide -with an estimated mortality of more than 11,000 people- and generated losses of US \$ 132 billion (CRED, 2019).

The occurrence of natural disasters involves profound changes in the living conditions of the affected communities (Economic Commission for Latin America and the Caribbean [ECLAC], 2014). First, the evidence suggests lower economic growth after a disaster (Klomp and Valckx, 2014; Lazzaroni and van Bergeijk, 2014). In turn, natural disasters affect the formation of human capital. On the one hand, they can destroy educational and health centers or the transport infrastructure of the affected areas. On the other hand, if they affect household

\footnotetext{
"Visión de Futuro" Año 18, Volumen No 25 N 1, Enero - Junio 2021 - Pág 62 -74

URL de la Revista: http://visiondefuturo.fce.unam.edu.ar/index.php/visiondefuturo/index

URL del Documento: https://visiondefuturo.fce.unam.edu.ar/index.php/visiondefuturo/issue/view/19

ISSN 1668 - 8708 - Versión en Línea

E-mail: revistacientifica@fce.unam.edu.ar
} 
income, the demand for human capital may be reduced given the lower disposable income and an increase in the marginal utility of child labor (Ferreira and Schady, 2008). The effects of disasters were also examined in dimensions such as health (Maclean et al., 2016; Hikichi et al., 2019; Ogasawara, 2019), poverty (Sánchez and Calderón, 2015; González et al., 2019; 2020) or education (Caruso, 2017).

Given the potential effects of natural disasters, it is essential to have a consistent methodology that allows quantifying their socio-economic impact and facilitates the implementation of mitigation and prevention actions. However, nowadays, the existence of multiple methodologies is observed. Thus, ECLAC (2003) has proposed a damage classification frequently used by the disaster literature: direct effects to refer to the physical damage caused by the disaster (includes damage to assets, mortality and morbidity) and indirect effects when considering the impact on productive flows. In a similar way, the World Bank (2010) distinguishes between first order effects (assimilable to direct effects) and higher order effects (effects of order $n$ resulting from effects of order $n-1)^{1}$.

Meyer et al. (2013) disaggregate the damage caused by disasters into five types: direct effects (destruction of physical assets), indirect effects (loss of salary, employment, etc.), business interruption costs (less production of goods and services), intangible costs (impact on health or the environment and in general goods not exchanged in a market) and mitigation costs (spending on reducing the future risk of disaster in affected areas). In order to avoid double counting the damage, Merz et al. (2010) consider that, since the value of an asset is equal to the discounted flow of its expected future benefits, a damage assessment methodology should not consider direct and indirect effects simultaneously. Therefore, it is evident that when considering the economic impact of a disaster, different elements and types of damage can arise. Logically, the use of different methodologies can lead to wide differences in damage estimates for the same disaster (Ladds et al., 2017; Avelino and Dall'erba, 2019).

Considering the above, this work provides a review of existing methodologies for evaluating the impact of natural disasters. In particular, it tries to identify similarities and differences in the quantification of damage and potential methodological gaps. Therefore, hereinafter section 2 describes the search methodology and information sources used. Section 3 presents the results of the review and, finally, section 4 discusses the main conclusions.

\footnotetext{
1. Thus, damage to a factory is a first-order effect, while lower production due to damage is a secondorder effect. If, in turn, as a result of the lower production of this factory, some other company sees its activity reduced or interrupted (eg. lack of inputs), a third-order effect occurs, and so on.

"Visión de Futuro" Año 18, Volumen No 25 N 1, Enero - Junio 2021 - Pág 62 -74

URL de la Revista: http://visiondefuturo.fce.unam.edu.ar/index.php/visiondefuturo/index

URL del Documento: https://visiondefuturo.fce.unam.edu.ar/index.php/visiondefuturo/issue/view/19

ISSN 1668 - 8708 - Versión en Línea

E-mail: revistacientifica@fce.unam.edu.ar
} 


\section{DEVELOPMENT}

\section{Methodology and sources of information}

Given the objective of the work, we proceed with a systematic review of the literature. The review is qualitative in nature. That is, we explore the heterogeneity observed between the relevant studies, identifying coincidences and dissimilarities from a descriptive perspective.

The literature review was carried out based on keyword searches in two well-known search engines (Scopus and Science Direct). In particular, the descriptors "impact assessment", "methodology" and "natural disasters" and their equivalents in Spanish were used. Neither temporal (according to publication date) nor geographic (place of publication) restrictions were considered. Additionally, the official websites of institutions with extensive experience in the study of disasters (ECLAC, the World Bank, the Federal Emergency Management Agency [FEMA] and the World Meteorological Organization) were considered.

The selection of relevant documents was made differentiating those contributions that constitute a method for measuring any effect of disasters, from those that are comprehensive methodologies. In terms of Eckhardt et al. (2019), a method is a formal prescription for achieving an objective -including a consistent set of tools and techniques- and that has a limited range of application. In this regard, various methods have been applied in estimating the effects of natural disasters -input-output matrices (Galbusera and Giannopoulos, 2018), computed general equilibrium models (Kajitani and Tatano, 2017), social accounting matrices (Okuyama, 2007), regression analysis (Klomp and Valckx, 2014; Lazzaroni and van Bergeijk, 2014) or multi-criteria analysis (Khalid and Ali, 2019). A methodology, on the other hand, constitutes a consistent and coherent set of methods to achieve an objective. Thus, the methodology proposed by FEMA suggests the use of replacement costs for the analysis of damage to physical assets and the use of input-output matrices when examining economic flows. In turn, those disaster risk assessment methodologies -as opposed to impact assessment- are beyond the scope of the analysis (Grimaz and Malisan, 2020). This work builds on the proposal of Eckhardt et al. (2019).

Considering the above, the keyword search yielded a total of 2,028 documents. After reading the title and abstract, 15 representative documents of 14 methodologies were selected (ECLAC updated in 2014 a previous methodology from 2003 and, therefore, two documents correspond). This selection was made considering the exclusion criteria presented above (works that do not constitute methodologies but methods were discarded). Table 1 summarizes the selected documents:

\footnotetext{
"Visión de Futuro" Año 18, Volumen No 25 N 1, Enero - Junio 2021 - Pág 62 -74 URL de la Revista: http://visiondefuturo.fce.unam.edu.ar/index.php/visiondefuturo/index

URL del Documento: https://visiondefuturo.fce.unam.edu.ar/index.php/visiondefuturo/issue/view/19

ISSN 1668 - 8708 - Versión en Línea

E-mail: revistacientifica@fce.unam.edu.ar
} 
Table 1: Methodologies for evaluating the impact of natural disasters

\begin{tabular}{|c|c|c|}
\hline Reference & Institution & Denomination \\
\hline $\begin{array}{l}\text { Calderón } \\
\text { Patier et al. } \\
(2003)\end{array}$ & Individual & Not specified \\
\hline IASC (2009) & Inter-Agency Standing Commitee & Initial Rapid Assessment (IRA) \\
\hline $\begin{array}{l}\text { Petrucci et al. } \\
\quad(2009)\end{array}$ & Individual & Suppor tAnalysis Framework (SAF) \\
\hline $\begin{array}{l}\text { World Bank et } \\
\text { al (2013) }\end{array}$ & $\begin{array}{l}\text { World Bank, European Comission and } \\
\text { United Nations Development Group }\end{array}$ & $\begin{array}{c}\text { Post Disaster Needs Assessment } \\
\text { (PDNA) }\end{array}$ \\
\hline $\begin{array}{l}\text { Dorra et al. } \\
(2013)\end{array}$ & Individual & Not specified \\
\hline $\begin{array}{l}\text { WMO and } \\
\text { GWP (2013) }\end{array}$ & $\begin{array}{l}\text { World Meteorological Organization and } \\
\text { Global Water Partnership }\end{array}$ & Not specified \\
\hline $\begin{array}{l}\text { ECLAC (2003; } \\
\text { 2014) }\end{array}$ & $\begin{array}{c}\text { Economic Commission for Latin America } \\
\text { and the Caribbean }\end{array}$ & $\begin{array}{c}\text { Damage and Losses Assessment } \\
\text { (DaLA) }\end{array}$ \\
\hline AIDR (2015) & Australian Institute for Disaster Resilience & Not specified \\
\hline IASC (2015) & Inter-Agency Standing Commitee & $\begin{array}{c}\text { Multi-cluster/sector Initial Rapid } \\
\text { Assessment (MIRA) }\end{array}$ \\
\hline $\begin{array}{l}\text { Lombardi et al. } \\
\text { (2016) }\end{array}$ & Individual & Not specified \\
\hline $\begin{array}{l}\text { Milan } \\
\text { Polytechni cet } \\
\text { al. (2017) }\end{array}$ & $\begin{array}{c}\text { Milan Polytechnic, Consejo Superior de } \\
\text { Investigaciones Científicas and Oxford } \\
\text { BrooksUniversity }\end{array}$ & $\begin{array}{l}\text { Improving Damage Assessments to } \\
\text { Enhance cost-benefit Analysis } \\
\text { (IDEA) }\end{array}$ \\
\hline FEMA (2018) & Federal Emergency Management Agency & Hazards-United States (HAZUS) \\
\hline $\begin{array}{l}\text { Nunes et al. } \\
(2020)\end{array}$ & Individual & Not specified \\
\hline $\begin{array}{l}\text { Sangha et al. } \\
(2020)\end{array}$ & Individual & Not specified \\
\hline
\end{tabular}

Source: own elaboration

It is observed that the existing methodologies come from both official institutions (8) and proposals from researchers (6). The growing interest in the study of natural disasters is evident considering that 7 of the methodologies were published in the last five years. In this sense, the number of documents identified from the keyword search also shows an increasing trend:

\footnotetext{
"Visión de Futuro" Año 18, Volumen $N^{0} 25$ No 1, Enero - Junio 2021 - Pág 62 -74

URL de la Revista: http://visiondefuturo.fce.unam.edu.ar/index.php/visiondefuturo/index

URL del Documento: https://visiondefuturo.fce.unam.edu.ar/index.php/visiondefuturo/issue/view/19

ISSN 1668 - 8708 - Versión en Línea

E-mail: revistacientifica@fce.unam.edu.ar
} 


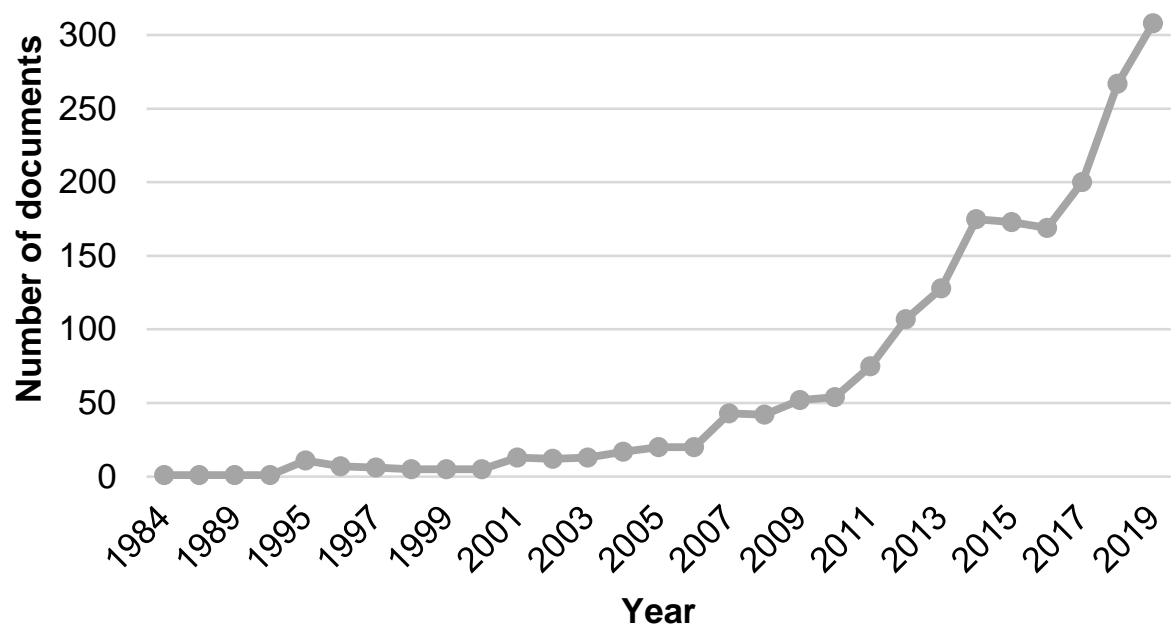

Figure 1: Number of documents resulting from keyword search

Source: own elaboration based on Scopus and Science Direct

It is observed that, especially since 2006, the number of documents referring to natural disasters increases significantly. This may be linked to the occurrence of disasters with broad socio-economic consequences such as the Sumatra-Andaman earthquake (2004) and Hurricane Katrina (2005) (Okuyama, 2007).

\section{Results}

Next, Table 2 presents each of the selected methodologies and includes a brief description, damages included, valuation methods used, sources of information and types of natural disasters contemplated.

\footnotetext{
"Visión de Futuro" Año 18, Volumen No 25 N 1, Enero - Junio 2021 - Pág 62 -74

URL de la Revista: http://visiondefuturo.fce.unam.edu.ar/index.php/visiondefuturo/index

URL del Documento: https://visiondefuturo.fce.unam.edu.ar/index.php/visiondefuturo/issue/view/19

ISSN 1668 - 8708 - Versión en Línea

E-mail: revistacientifica@fce.unam.edu.ar
} 
Table 2: Description of impact assessment methodologies for natural disasters

\begin{tabular}{|c|c|c|c|c|c|}
\hline Reference & Type of damages & Description & $\begin{array}{l}\text { Valuation } \\
\text { method }\end{array}$ & $\begin{array}{l}\text { Sources of } \\
\text { information }\end{array}$ & Types of disasters \\
\hline $\begin{array}{l}\text { CalderónPatier } \\
\text { et al. (2003) }\end{array}$ & $\begin{array}{l}\text { Distinguishes between } \\
\text { direct effects (on physical } \\
\text { assets) and indirect effects } \\
\text { (less production of goods } \\
\text { and services). Considers } \\
\text { secondary effects (lower } \\
\text { macroeconomic flows) }\end{array}$ & $\begin{array}{l}\text { Based on the use of input-output } \\
\text { matrices, Tries to estimate the socio- } \\
\text { economic impact of disasters and } \\
\text { prepare recovery plans }\end{array}$ & $\begin{array}{l}\text { Replacement } \\
\text { cost and } \\
\text { observed } \\
\text { changes in } \\
\text { economic flows }\end{array}$ & $\begin{array}{l}\text { Input-output } \\
\text { matrices, } \\
\text { national } \\
\text { accounts, } \\
\text { macroeconomic } \\
\text { indicators, etc. }\end{array}$ & $\begin{array}{l}\text { Natural of all kinds. Also } \\
\text { applicable to anthropogenic } \\
\text { disasters }\end{array}$ \\
\hline IASC (2009) & $\begin{array}{l}\text { Distinguishes the impact by } \\
\text { categories (population, } \\
\text { shelter, health services, } \\
\text { nutrition and health). } \\
\text { Proposespotentialindicators } \\
\text { to use }\end{array}$ & $\begin{array}{l}\text { It is a tool that provides an overview } \\
\text { of an emergency situation, based on } \\
\text { multi-sectoral information, identifies } \\
\text { impacts and needs and determines } \\
\text { priority humanitarian actions in the } \\
\text { first weeks after the disaster }\end{array}$ & $\begin{array}{l}\text { Qualitative scale } \\
\text { of severity by } \\
\text { category } \\
\text { (severe, } \\
\text { worrying or } \\
\text { normal) }\end{array}$ & $\begin{array}{l}\text { Household } \\
\text { surveys, } \\
\text { strategic } \\
\text { informants, } \\
\text { group } \\
\text { discussions, } \\
\text { secondary data } \\
\text { on previous } \\
\text { demographic } \\
\text { and climatic } \\
\text { conditions }\end{array}$ & Natural of all kinds \\
\hline $\begin{array}{l}\text { Petrucci et al. } \\
(2009)\end{array}$ & $\begin{array}{l}\text { Considers direct damage } \\
\text { (destruction of buildings, } \\
\text { roads and physical damage } \\
\text { to people), indirect damage } \\
\text { (reduction in productivity } \\
\text { and displacement of } \\
\text { people) and intangible } \\
\text { damage (psychological or } \\
\text { emotional consequences } \\
\text { on people) }\end{array}$ & $\begin{array}{l}\text { Through questionnaires by category, } \\
\text { normalized numerical damage } \\
\text { indices are generated for the case of } \\
\text { mass movements in Calabria-ltaly }\end{array}$ & $\begin{array}{l}\text { Quali- } \\
\text { quantitative by } \\
\text { generating } \\
\text { index numbers }\end{array}$ & $\begin{array}{l}\text { Historical } \\
\text { records of } \\
\text { disasters, } \\
\text { technical reports, } \\
\text { municipal } \\
\text { reports, local } \\
\text { newspapers, etc. }\end{array}$ & 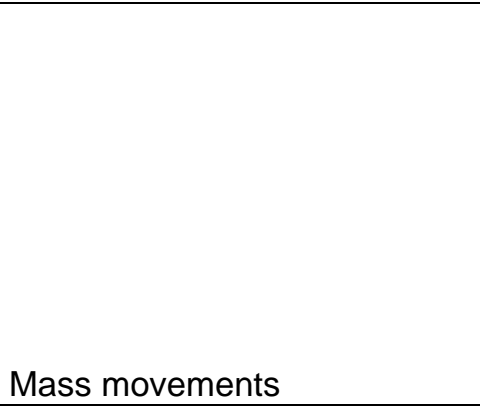 \\
\hline $\begin{array}{l}\text { World Bank et al. } \\
(2013)\end{array}$ & $\begin{array}{l}\text { Distinguishes between } \\
\text { effects (damage to } \\
\text { infrastructure, less access } \\
\text { to services, greater } \\
\text { vulnerability of people) and }\end{array}$ & $\begin{array}{l}\text { The methodology consists of a guide } \\
\text { to help governments assess the } \\
\text { damage generated by natural } \\
\text { disasters and formulate recovery } \\
\text { strategies and their implementation }\end{array}$ & $\begin{array}{l}\text { Replacement } \\
\text { cost for damage } \\
\text { to physical } \\
\text { assets and } \\
\text { analysis of time }\end{array}$ & $\begin{array}{l}\text { Censuses, } \\
\text { economic } \\
\text { reports, } \\
\text { household } \\
\text { surveys, remote }\end{array}$ & Natural of all kinds \\
\hline
\end{tabular}

\section{“Visión de Futuro" Año 18, Volumen $N^{\circ} 25$ No 1, Enero - Junio 2021 - Pág 62 -74}

URL de la Revista: http://visiondefuturo.fce.unam.edu.ar/index.php/visiondefuturo/index

URL del Documento: https://visiondefuturo.fce.unam.edu.ar/index.php/visiondefuturo/issue/view/19

ISSN 1668 - 8708 - Versión en Línea

E-mail: revistacientifica@fce.unam.edu.ar 
impacts of disasters
(macroeconomic r and
human development

consequences) evolution in sensor images,

macroeconomic strategic

aggregates and informants,

development national

indicators (HDI, accounts, etc.

MPI, etc.)

Presents a probabilistic model for estimating losses (especially considering losses in buildings and

Distinguishes between gas and electricity networks). A

direct (on physical assets) macroeconomic model is also

Dorra et al. and indirect (lower developed from input-output (2013) economic flows) damages matrices

Distinguishes between

damages (on physical

assets) and losses (lower

economic flows). It also

incorporates intangible

WMO and GWP losses (human lives,

(2013)

injuries, etc.)

Considers direct (on the

assets and infrastructure of

the affected area) and

indirect (lower economic

flows from the disaster)

damages. Also includes

"macroeconomic effects" as

ECLAC (2003; a result of direct and indirect

2014)

Replacement

cost, observed Censuses,

changes in surveys, building

economic flows inventories,

and fragility input-output

curves matrices, etc.

Replacement information

cost, observed systems, land

changes in use and building

It is a tool to assess flood losses and economic flows reports, surveys,

generate recovery plans. Proposes and damages strategic

pre and post disaster evaluations

Analyzes

conceptual

curves

measurement of damage caused by

disasters. Take a micro-macro

perspective. Damage can be

estimated from information from

multiple affected sectors but also

from macroeconomic aggregates damages.

that condense information from all sectors

Written press,

Replacement cartography,

costs for direct surveys, remote

damages and sensor images,

counterfactual strategic

analysis for informants,

indirect national

damages accounts, etc.

Earthquakes

informants, etc. Floods

Distinguishes between

direct damage (physical

destruction of assets) and

indirect (lower economic

flows). In each case

Constitutes a guide to estimate the

economic costs of natural disasters

in Australia. Proposes pre and post

AIDR (2015) disaggregates between disaster evaluations

Natural of all kinds. Also

applicable to anthropogenic

Replacement Interviews, focus

costs for direct groups,

damages and meteorological

oss of added office,

value for indirect government

damages. Also reports, etc.

Natural of all kinds

URL del Documento: https://visiondefuturo.fce.unam.edu.ar/index.php/visiondefuturo/issue/view/19

ISSN 1668 - 8708 - Versión en Línea

E-mail: revistacientifica@fce.unam.edu.ar 
tangible losses (goods that can be sold in a market) and intangible losses (human lives)

Considers primary effects

(damage to infrastructure),

secondary effects (less

economic flows and the

impact of disasters

generated as a

consequence of a previous

disaster) and humanitarian

needs (mortality, morbidity

IASC (2015) etc.)

Distinguishes between damages (on physical assets) and losses (lower productive flows) for each agricultural subsector.

Lombardi et al. Suggest indicators to be (2016) used in each case for indirect

damage, higher

cost of provision

or operation

\begin{tabular}{|c|c|c|}
\hline $\begin{array}{l}\text { Replacement } \\
\text { cost and } \\
\text { observed in } \\
\text { changes flows } \\
\text { economic }\end{array}$ & $\begin{array}{l}\text { Household } \\
\text { surveys, } \\
\text { strategic } \\
\text { informants, in } \\
\text { discussion in } \\
\text { community } \\
\text { groups, } \\
\text { secondary data, } \\
\text { etc. }\end{array}$ & Natural of sudden ocurrence \\
\hline $\begin{array}{l}\text { Replacement } \\
\text { ost and } \\
\text { observed } \\
\text { changes in } \\
\text { conomic flows }\end{array}$ & $\begin{array}{l}\text { Agricultural } \\
\text { surveys, satellite } \\
\text { images, climate } \\
\text { indicators, etc. }\end{array}$ & Natural of all kinds \\
\hline $\begin{array}{l}\text { Replacement } \\
\text { cost and } \\
\text { boserved } \\
\text { changes in } \\
\text { economic flows }\end{array}$ & $\begin{array}{l}\text { Highlights the } \\
\text { importance of } \\
\text { information from } \\
\text { insurers and } \\
\text { state agencies }\end{array}$ & Natural of all kinds \\
\hline $\begin{array}{l}\text { Consider } \\
\text { replacement } \\
\text { cost for direct } \\
\text { physical } \\
\text { damage. It also } \\
\text { uses } \\
\text { probabilistic }\end{array}$ & $\begin{array}{l}\text { The software } \\
\text { includes } \\
\text { databases that } \\
\text { are used as a } \\
\text { source. They } \\
\text { contain } \\
\text { information on }\end{array}$ & $\begin{array}{l}\text { Earthquakes, floods, tsunamis } \\
\text { and hurricanes }\end{array}$ \\
\hline
\end{tabular}
probabilistic information on and hurricanes

\section{"Visión de Futuro" Año 18, Volumen $\mathbf{N}^{\mathbf{0}} 25 \mathbf{N}^{\mathbf{0}}$ 1, Enero - Junio 2021 - Pág 62 -74} purposes (including damage direct (On mitigation, and MilanPolytechnic and indirect (lower agencies). Emphasis on cost-benefit et al. (2017) economic flows) damages Distinguishes between direct physical damage (damage to buildings, public services, transportation and essential facilities -health,

It is a needs assessment tool in disaster. Proposes a comprehensive conditions, damage caused and humanitarian responses

Proposes a methodology to estimate Replacement

the impact of natural disasters in the sector (emphasis on and forestry) Provides a methodology for collecting, analyzing, and using disaster loss data for multiple

Based on geographic information systems, it estimates the potential impact, economic losses and social impact of disasters. Includes

URL de la Revista: http://visiondefuturo.fce.unam.edu.ar/index.php/visiondefuturo/index

URL del Documento: https://visiondefuturo.fce.unam.edu.ar/index.php/visiondefuturo/issue/view/19

ISSN 1668 - 8708 - Versión en Línea

E-mail: revistacientifica@fce.unam.edu.ar 

rubble, trees and fires) and direct losses (furniture for buildings, inventories, income and people injured or displaced) (damage generated by models such as loss curves and

input-output matrices. the stock

buildings,

transport

systems,

services and

demographic

data. In addition,

the user can

incorporate

external sources

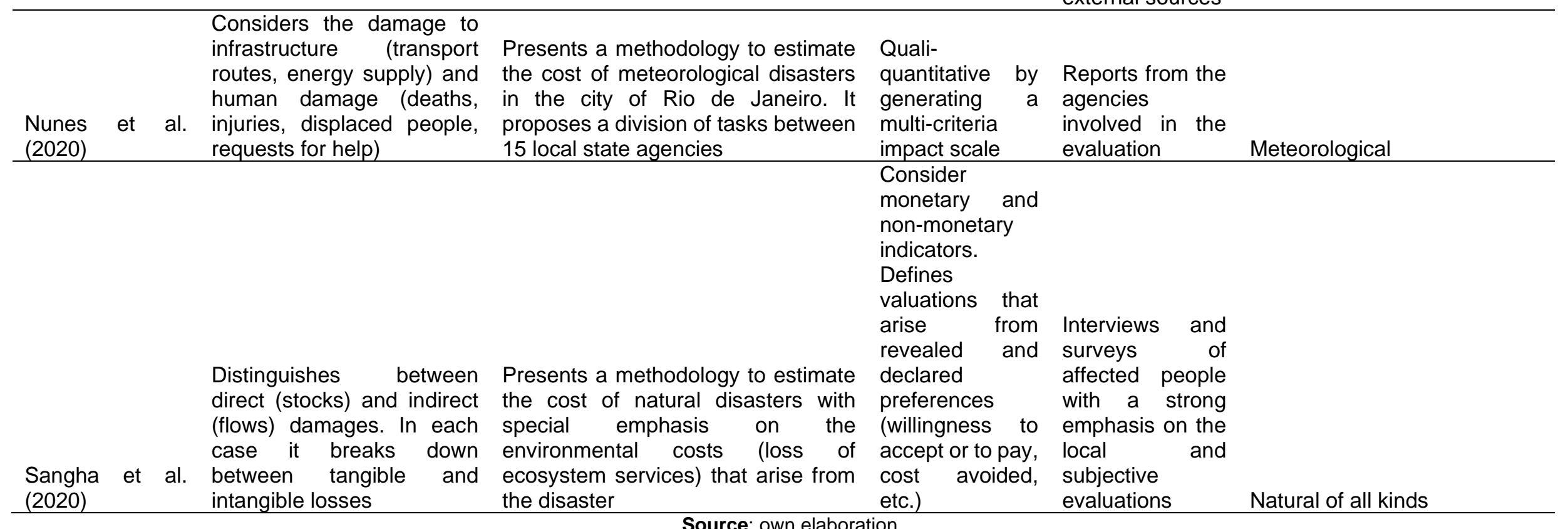

"Visión de Futuro" Año 18, Volumen No 25 No 1, Enero - Junio 2021 - Pág 62 -74

URL de la Revista: http://visiondefuturo.fce.unam.edu.ar/index.php/visiondefuturo/index

URL del Documento: https://visiondefuturo.fce.unam.edu.ar/index.php/visiondefuturo/issue/view/19

ISSN 1668 - 8708 - Versión en Línea

E-mail: revistacientifica@fce.unam.edu.ar 
First, Table 2 shows some points in common and also differences in the analyzed methodologies. In relation to the types of damage considered, studies tend to discriminate between the physical damage resulting from the disaster (direct effect, damage or first order effect) and the impact on productive flows (indirect effect, loss or second order effect). However, only some of the methodologies explicitly disaggregate the impact on the physical integrity of exposed people -mortality, injuries, etc.- (IASC, 2009; Petrucciet al., 2009; World Bank et al., 2013; WMO and GWP, 2013; AIDR, 2015; IASC, 2015; FEMA, 2018; Nunes et al., 2020).

In the particular case of the so-called direct effects, some methodologies delimit the sectors or types of assets on which information is collected. Thus, housing or sanitary and health facilities (IASC, 2009), transportation networks (Petrucci et al., 2009; Nunes et al., 2020), access to services (World Bank et al., 2013; Nunes et al., 2020) and essential facilities -health centers, education or emergency assistance- (FEMA, 2018). This realizes the importance of these sectors in terms of the capacity of a community to face a natural disaster and its potential effects.

Observing the valuation criteria used, it appears that the replacement cost of the destroyed assets is the most frequently used to quantify the direct effects. In terms of indirect effects, the changes observed in the main macroeconomic aggregates is the most widely used criterion. In this regard, ECLAC (2003) remarks that the use of the book value of assets -when evaluating direct effects- lacks representativeness in countries with a history of moderate or high inflation.Also, when considering indirect effects it is necessary to estimate what the evolution of the variables of interest (counterfactual analysis) in case the disaster had not taken place -in order to individualize the effect of the disaster itself-. Partially departing, Merz et al. (2010) argue that using replacement cost can overestimate the damage caused by the disaster by ignoring the depreciation of the damaged asset -recommending the use of the acquisition cost net of depreciations.

On the other hand, discrepancies are also observed in the methods to be used. Thus, some methodologies propose to use probabilistic models -such as damage or fragility curves- (Dorra et al., 2013; WMO and GWP, 2013; FEMA, 2018), while others resort to qualitative-quantitative indices (IASC, 2009; Petrucci et al., 2009; Nunes et al., 2020). This, logically, can lead to wide differences between estimates of different methodologies -as shown by Ladds et al. (2017) and Avelino and Dall'erba (2019)-.

In terms of the sources of information, there is a wide use of on-site surveys, interviews with key informants, government reports and newspaper articles. When estimating indirect effects, input-output matrices are used (CalderónPatier et al., 2003; Dorra et al., 2013; FEMA, 2018) and information from the national accounts (ECLAC, 2003; 2014; CalderónPatier et al., 2003; World Bank et al., 2013). In terms of the types of disaster analyzed, the methodologies tend to consider 
all natural disasters with exceptions such as Petrucci et al. (2009), Dorra et al. (2013), WMO and GWP (2013), FEMA (2018) and Nunes et al. (2020).

In terms of the existence of gaps in the methodological proposals analyzed, the following can be highlighted. First, there is a clear bias towards the analysis of direct effects. The level of detail and disaggregation in this case is usually higher compared to the analysis of indirect effects, in addition to that, although direct effects are included in all the reviewed antecedents, not all consider indirect effects (IASC, 2009; Nunes et al., 2020). In the same sense, conceiving of indirect effects as the observed changes in the variables of interest -before and after the occurrence of the disaster- can be an oversimplification and confuse the effect of a disaster with other simultaneous events.

Second, the environmental cost (loss of ecosystem services) does not seem to be explicitly considered in the methodologies examined, with the exception of ECLAC (2003; 2014), World Bank et al. (2013) and Sangha et al. (2020). This is especially important given that subjective well-being seems to be directly linked to the availability of environmental assets and the benefits they provide (Sangha et al., 2020).

Third, the methodologies reviewed tend to construct their estimates of indirect effects from the availability of periodic and disaggregated information on relevant macroeconomic variables such as GDP, employment series, income, etc.-. While this is a reasonable assumption for countries with robust statistical systems, it may not be so in developing countries where disaggregated statistics are scarce. In any case, methodological proposals should explicitly consider this possibility to guide the analyst in estimating damages.

Fourth, in addition to estimating the total cost or damage produced after the occurrence of a natural disaster, it is also relevant to know how the cost is distributed within a community. In this sense, the methodologies reviewed do not contemplate an explicit treatment of people in poverty or greater vulnerability to the occurrence of disasters -even if they consider the impact of disasters on poverty or well-being. The exception to the above is given by the cases of WMO and GWP (2013) and IASC (2015).

Fifth, there is a certain gap in terms of the sources of information used by the methodologies examined and a growing body of empirical literature on disasters. Indeed, recent works estimate the impact of disasters or contribute to their detection -in real time- from data from social networks or collaborative platforms (Liu, 2014; Resch et al., 2017; Arthur et al., 2018; Kankanamge et al., 2020). It is striking that the most recent methodological proposals do not explicitly incorporate these sources of information.

Finally, an aspect pointed out by Merz et al. (2010) and Meyer et al. (2013) is the lack of validation of the estimates generated from each individually considered methodology. That is, 
each methodological proposal provides estimates of a certain type of damage using a certain method (example: input-output matrices or computed general equilibrium models) but without inquiring about the robustness of what was reported. In terms of policy makers, the reliability of the estimates is relevant, especially when considering the regulatory decisions behind the estimates (spatial and temporal delimitation for the evaluation, chosen valuation method, including sectors, among others). In this regard, recent evidence tries to account for the discrepancies between methods when evaluating the same disaster (Tan et al., 2019).

\section{CONCLUSIONS}

Throughout this work, we have provided a review of the literature regarding methodologies for evaluating the impact of natural disasters. From the search by keywords in two renowned search engines -Scopus, Science Direct- 14 methodological proposals were selected.

From the group of selected studies, it was observed that the majority (8) respond to institutional proposals (Economic Commission for Latin America and the Caribbean, World Bank, World Meteorological Organization, Federal Emergency Management Agency, among others) and not to works in scientific journals. Seven of the revised methodological proposals were published in the last five years. The foregoing denotes a growing interest in the study of the impacts of natural disasters.

When examining the selected methodologies in detail, points of coincidence and differences between them were observed. In all cases, the destruction of physical assets (direct effects) and, in general, also the changes in economic flows after the disaster (indirect effects) are considered. The use of replacement cost of damaged assets as a valuation criterion enjoys wide consensus even when some methodologies resort to the use of qualitative and quantitative damage indices. In terms of information sources, a large number of variants were observed: satellite images, interviews, government reports, econometric models, surveys, etc. In any case, interviews, reports and surveys are the most frequently used.

In terms of methodological gaps, it is possible to highlight the following. Damage estimation tends to focus on direct effects, to the detriment of other types of damage (indirect, intangible, etc.). Furthermore, methodological proposals usually assume the existence and availability of disaggregated and periodic macroeconomic information for the estimation of damages -which may not be realistic in developing countries. The non-use of certain sources of information -such as social networks or collaborative platforms- and the reduced consideration of the distribution of damages within the affected community are relevant aspects to include.

Finally, considering that an increase in the frequency and severityin the occurrence of natural disasters is expected, and that these generate a severe interruption in the operation of

\footnotetext{
"Visión de Futuro" Año 18, Volumen $N^{0} 25$ N 1, Enero - Junio 2021 - Pág 62 -74

URL de la Revista: http://visiondefuturo.fce.unam.edu.ar/index.php/visiondefuturo/index

URL del Documento: https://visiondefuturo.fce.unam.edu.ar/index.php/visiondefuturo/issue/view/19

ISSN 1668 - 8708 - Versión en Línea

E-mail: revistacientifica@fce.unam.edu.ar
} 
the affected community, it is essential to have a consistent methodology for evaluating their impact. For this, it is essential to have regular socio-economic information and an adequate historical record of natural disasters.

\section{REFERENCES}

Please refer to articles in Spanish Bibliography.

\section{BIBLIOGRAPHICAL ABSTRACT}

Please refer to articles in Spanish Bibliographical abstract. 